\section{US climate-research shake-up recommended}

The US government's climateresearch programme should adopt an interdisciplinary approach that engages policy-makers to address adaptation and mitigation strategies. That's the conclusion of a National Research Council committee report, released on 26 February.

The committee found that the Climate Change Science Program (CCSP) has been hindered by a lack of research into the social sciences, which has never garnered more than $3 \%$ of the programme budget. The CCSP should address issues at the local and regional levels, including the effects of drought, extreme weather and shifting ecosystems.

The report recommends that the programme establish a "climate observing system" that includes the physical, biological and social aspects of global warming. The committee also recommended that, instead of issuing separate reports on different topics, the CCSP should return to a single national assessment involving stakeholders across all disciplines and agencies.

\section{Italy plans nuclear plants in cooperation with France}

Respective Italian and French energy utilities Enel and EDF last week agreed a joint venture aimed at building four new nuclear reactors in Italy.

The plants would be the first to be built in the country since a national referendum in 1987, held in the wake of the Chernobyl reactor accident, shut down Italy's nuclear power industry.

\title{
Obama has second go at choosing US health chief
}

Governor Kathleen Sebelius of Kansas (Democrat) was nominated to head the US Department of Health and Human Services by President Barack Obama on 2 March. If confirmed by the US Senate, Sebelius (pictured) will play a key role as the president seeks to overturn restrictions on federal funding for human embryonic stem-cell research (see Nature 457, 1068-1069; 2009)

Sebelius's nomination may speed the naming of other leaders in the vast department of 65,000 employees, including the chiefs of the National Institutes of Health, the Food and Drug Administration and the Centers for Disease Control and Prevention.

The nomination comes a month after a previous nominee, Thomas Daschle, formerly the top Democrat in the Senate, withdrew under fire for failing to pay $\$ 128,000$ in back taxes.

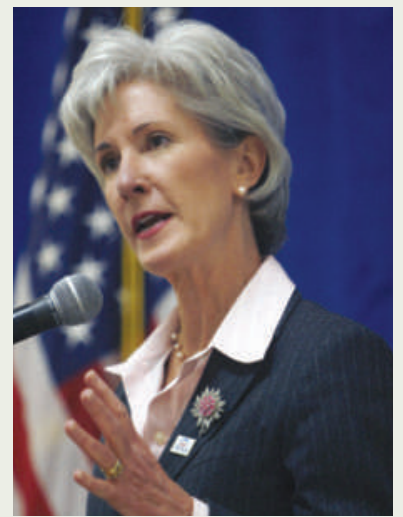

The deal accompanied an agreement on nuclear cooperation between the French and Italian governments signed on 23 February. Enel says it aims for the first plant to be operative by 2020 , which London-based nuclear consultant John Large describes as a "very tight" deadline. High capital costs, local protests at sites as they are selected, and an insufficient regulatory framework to satisfy private investors could yet stymie the plans, says Large.

Industry minister Claudio Scajola said parliament would pass legislation in April paving the way for an Italian nuclear revival.

\section{Korean egg-donor lawsuit thrown out of court}

On 18 February, Seoul District Court in South Korea rejected a lawsuit about the egg-donation procedures used in the cloning research of disgraced former Seoul National University researcher Woo Suk Hwang.

Two women brought the lawsuit against the Korean government, MizMedi Hospital and Hanyang University Hospital in April 2006. The women had donated eggs for Hwang's research at those hospitals (see Nature 440, 1102; 2006).

The women claimed that they had suffered physical and psychological damage because they were not informed about the risks of the procedure, and that the Korean government bore some responsibility because of its uncritical support of Hwang's research. The lawsuit, which requested 32 million Korean won (US\$20,000) in damages, was supported by more than 30 women's advocacy groups.

The government's legal case against Hwang on counts of fraud, embezzlement and violation of the country's bioethics law continues.

\section{Ranbaxy censured by FDA over falsified data}

Ranbaxy Laboratories - India's biggest drug maker and one of the largest generics firms in the world - has been slapped with tough penalties by the US Food and Drug Administration (FDA) after it was caught repeatedly falsifying data from one of its four Indian manufacturing plants.

The FDA action revokes some 25 existing approvals of drugs made at Ranbaxy's factory at Paonta Sahib in Himachal Pradesh, and stops an unnamed number of pending applications for drugs from the same plant.

Details released by the agency on 25 February reveal that, since at least 2006, Ranbaxy employees refrigerated samples that were supposed to be stored at room temperature to test their stability over time. In another instance, the plant misreported stability test results that were conducted over days instead of months.

The company issued a written statement saying that it "will continue to cooperate" with the US agency.

For a longer version of this story see http://tinyurl.com/ba5tnk 